\title{
Rhodovulum marinum sp. nov., a novel phototrophic purple non-sulfur alphaproteobacterium from marine tides of Visakhapatnam, India
}

\author{
T. N. R. Srinivas, ${ }^{1}$ P. Anil Kumar, ${ }^{1}$ Ch. Sasikala, ${ }^{1}$ Ch. V. Ramana, ${ }^{2}$ J. Süling ${ }^{3}$ \\ and J. F. Imhoff ${ }^{3}$ \\ ${ }^{1}$ Environmental Microbial Biotechnology Laboratory, Centre for Environment, Institute of \\ Science and Technology, J. N. T. University, Kukatpally, Hyderabad 500 072, India \\ ${ }^{2}$ Department of Plant Sciences, School of Life Sciences, University of Hyderabad, PO Central \\ University, Hyderabad 500 046, India \\ ${ }^{3}$ Leibniz-Institut für Meereswissenschaften, Marine Mikrobiologie, Düsternbrooker Weg 20, \\ 24105 Kiel, Germany
}

Correspondence

Ch. V. Ramana

r449@sify.com sasi449@yahoo.ie

\begin{abstract}
A yellowish-brown bacterium was isolated from enrichment cultures inoculated with seawater samples from the eastern coast of India (Visakhapatnam) under photoheterotrophic conditions. Enrichment and isolation in a medium containing $2 \% \mathrm{NaCl}(\mathrm{w} / \mathrm{v})$ yielded strain $\mathrm{JA} 128^{\top}$, which has ovoid to rod-shaped cells, also forms chains and is non-motile. Phylogenetic analysis on the basis of $16 \mathrm{~S}$ rRNA gene sequences showed that strain $\mathrm{JA} 128^{\top}$ clusters with the Alphaproteobacteria and the sequence similarity with its closest relatives, Rhodovulum iodosum and Rhodovulum sulfidophilum, was $95 \%$. Strain JA128 ${ }^{\top}$ contained vesicular intracytoplasmic membranes, bacteriochlorophyll $a$ and carotenoids of the spheroidene series. Strain JA128 ${ }^{\top}$ was mesophilic, slightly acidophilic, slightly halophilic and grew photoheterotrophically with a number of organic compounds as carbon source and electron donor. It was unable to grow photoautotrophically, chemoautotrophically or by fermentative modes. It did not utilize sulfide, thiosulfate or hydrogen as electron donors. Thiamine was required as a growth factor. Based on the 16S rRNA gene sequence analysis, morphological and physiological characteristics, strain JA128 ${ }^{\top}$ was significantly different from other species of the genus Rhodovulum and was recognized as a novel species for which the name Rhodovulum marinum sp. nov. is proposed. The type strain is $\mathrm{JA} 128^{\top}\left(=\right.$ ATCC BAA $1215^{\top}=$ CCUG $\left.52183^{\top}=\mathrm{JCM} 13300^{\top}\right)$.
\end{abstract}

Marine habitats represent excellent niches for anoxygenic phototrophic bacteria, which are widely distributed in numerous coastal marine habitats. Most common anoxygenic phototrophic bacteria have been isolated from estuarine salt pans, salt marshes (Imhoff et al., 1998a, b; Imhoff \& Pfennig, 2001), coastal lagoons with elevated salt concentrations (Imhoff et al., 1998a, b), tidal waters, brackish waters (Pfennig \& Trüper, 1989; Imhoff, 1988) and marine coastal sediments (Imhoff, 1983). They have even been found in the extreme marine habitats of Antarctica (Madigan et al., 2000; Karr et al., 2003).

Previously, the taxonomy of photosynthetic bacteria was based exclusively on phenotypical characteristics (Pfennig \&

The GenBank/EMBL/DDBJ accession number for the 16S rRNA gene sequence of strain JA128 ${ }^{\top}$ is AJ891122.
Trüper, 1974, 1989). A 16S rRNA gene sequence comparison of these bacteria revealed phylogenetic differences among freshwater, true marine and halophilic bacteria (Imhoff et al., 1998a). On the basis of these results, a number of taxa have been reclassified. The marine representatives of the genus Chromatium were transferred to the genera Allochromatium, Marichromatium, Isochromatium and Halochromatium (Imhoff et al., 1998a), while the marine Rhodobacter species were reclassified as species of the genus Rhodovulum (Hiraishi \& Ueda, 1994) and those of Rhodospirillum to Rhodothalassium and Roseospira (Imhoff et al., 1998b).

The marine anoxygenic phototrophic Gammaproteobacteria are distributed among the families Chromatiaceae and Ectothiorhodospiriaceae. In the Chromatiaceae, the genera Halochromatium, Thiohalocapsa, Thiococcus, Rhabdochromatium, Isochromatium, Thiorhodococcus, Marichromatium 
and Thiorhodovibrio (Imhoff et al., 1998a) grow in $\mathrm{NaCl}$ concentrations from 1 to $11 \%$. The Ectothiorhodospiraceae genera include Halorhodospira, Thiorhodospira and Ectothiorhodospira, growing in $\mathrm{NaCl}$ concentrations from 1 to $32 \%$ (Imhoff, 2001). Marine representatives of phototrophic Alphaproteobacteria that can grow in $1-12 \% \mathrm{NaCl}$ are found in the genera Rhodospira, Roseospirillum, Roseospira, Rhodobium, Rhodovulum, Rhodobaca, Rhodothalassium and Rhodovibrio (Imhoff, 2001). No marine representatives of anoxygenic phototrophic Betaproteobacteria have been reported so far. Apart from phylogenetic differences based on 16S rRNA gene sequences of marine and freshwater species of anoxygenic phototrophic bacteria, good correlations were also observed in the major quinone and fatty acid compositions, which were in accordance with the requirement of $\mathrm{NaCl}$ or sea salt for growth of some of these bacteria (Imhoff et al., 1998b).

We have isolated several strains of marine purple bacteria from coastal areas of Andhra Pradesh, India. Strain JA128 ${ }^{\mathrm{T}}$, isolated from photoheterotrophic enrichments of seawater from a tidal beach, had $95 \%$ 16S rRNA gene sequence homology with the type strains of Rhodovulum iodosum and Rhodovulum sulfidophilum, and $93 \%$ with Rhodovulum robiginosum. This isolate, based on phenotypic characteristics and significant differences in the 16S rRNA gene sequence, is described here as a novel species, Rhodovulum marinum sp. nov.

Tidal water samples from a beach at Visakhapatnam on the east coast of India (Bay of Bengal) were collected in polypropylene bottles during March 2004. The medium of Pfennig \& Trüper (1992) supplemented with $\mathrm{NaCl}(2 \%$ $\mathrm{w} / \mathrm{v})$, pyruvate $(0.3 \% \mathrm{w} / \mathrm{v})$ as carbon source and ammonium chloride $(0 \cdot 12 \%)$ as nitrogen source was used for photoheterotrophic growth under light (2400 lux) at $30 \pm 2{ }^{\circ} \mathrm{C}$. Purification was done by using the repeated agar shake dilution method (Pfennig \& Trüper, 1992;
Imhoff, 1988). Purified cultures were grown in completely filled screw cap test tubes $(10 \times 100 \mathrm{~mm})$ for photoheterotrophic growth.

Morphological properties (cell shape, cell division, cell size, flagella) were observed by phase-contrast light microscopy (Olympus BH-2), ultrastructure of flagella was studied after staining with $1 \%$ phosphotungstic acid and ultrathin sections for intracytoplasmic structures, such as the internal membrane system, were viewed through a transmission electron microscope (H-7500; Hitachi). In vivo absorption spectra were measured with a Spectronic Genesys 2 spectrophotometer in sucrose solution (Trüper \& Pfennig, 1981). Absorption spectra were also recorded from pigments extracted with acetone after eluting the cell suspension with acetone through a $10 \times 200 \mathrm{~mm}$ column packed with aluminium oxide. Utilization of other inorganic and organic compounds as electron donors for phototropic growth was tested without any additional electron donor in the presence of yeast extract $(0.03 \%, \mathrm{w} / \mathrm{v})$. Formic acid, propionate, butyrate, caproate, valerate, lactate, glycerol, methanol and ethanol were used at a concentration of $0 \cdot 1 \%(\mathrm{v} / \mathrm{v})$; other compounds tested were used at $0.3 \%(\mathrm{w} / \mathrm{v})$, with benzoate $(1 \mathrm{mM})$ and $\mathrm{NaHCO}_{3}(0 \cdot 1 \%)$. For testing sulfur sources, $\mathrm{MgSO}_{4} .7 \mathrm{H}_{2} \mathrm{O}$ was replaced by $\mathrm{MgCl}_{2} .5 \mathrm{H}_{2} \mathrm{O}(0.01 \%)$; sulfur sources $\left(\mathrm{Na}_{2} \mathrm{~S} .9 \mathrm{H}_{2} \mathrm{O}, \mathrm{Na}_{2} \mathrm{~S}_{2} \mathrm{O}_{3}\right.$, sodium thioglycolate, cysteine, $\mathrm{MgSO}_{4} .7 \mathrm{H}_{2} \mathrm{O}$, all at $0.5 \mathrm{mM}$, and $\mathrm{FeSO}_{4}, 10 \mathrm{mM}$ ) were added to the medium in addition to $\mathrm{NaHCO}_{3}(0 \cdot 1 \%)$. Nitrogen source utilization was tested by replacing ammonium chloride with different nitrogen sources at $0 \cdot 12 \%$ $(\mathrm{w} / \mathrm{v})$. Vitamin requirements were tested by replacing yeast extract with single and also combinations of vitamins as growth factors. Chemotrophy was determined by growing the cultures in Erlenmeyer flasks placed in an orbital shaker in the dark at $30^{\circ} \mathrm{C}$. Diazotrophy of the cultures was determined by growth under an $\mathrm{N}_{2}$ atmosphere and was confirmed by repeated subculturing (four times). Growth was measured turbidometrically at $660 \mathrm{~nm}$.
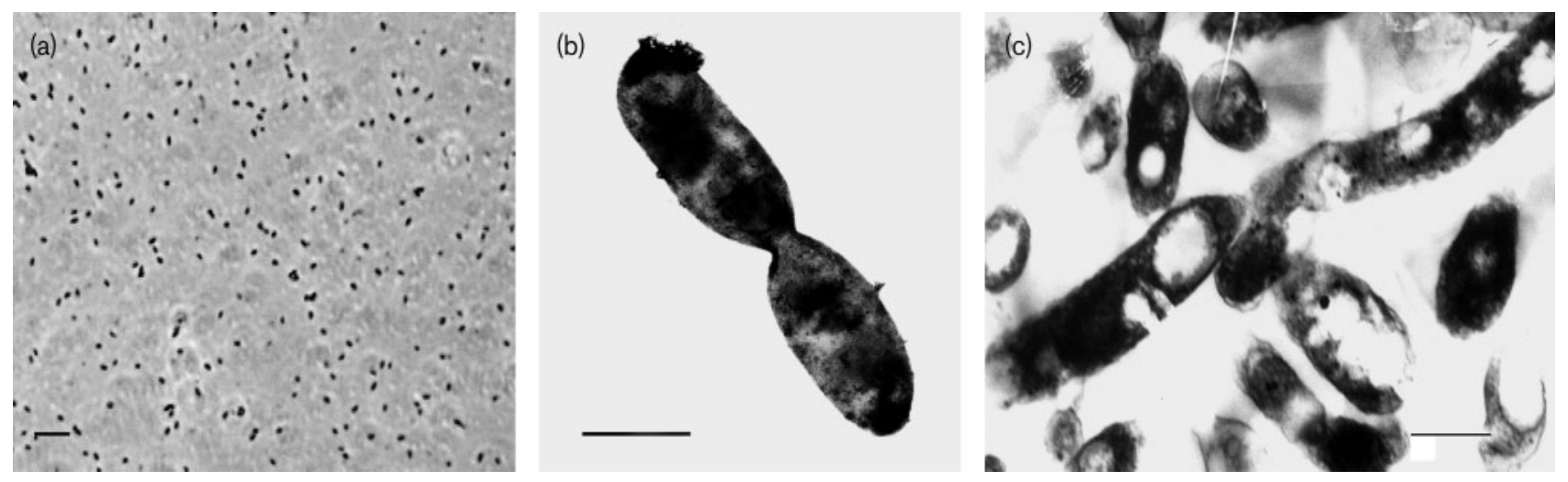

Fig. 1. (a) Phase-contrast micrograph of strain $J A 128^{\top}$. Bar, $5 \mu \mathrm{m}$. (b) Electron micrograph of negatively stained cells of strain $\mathrm{JA} 128^{\top}$ showing binary fission division. Bar, $1 \mu \mathrm{m}$. (c) Electron micrograph of ultrathin section of strain $\mathrm{JA} 128^{\top}$ showing the vesicular nature of the photosynthetic membranes extending throughout the cell. Bar, $0.5 \mu \mathrm{m}$. 
Table 1. Differentiating characteristics of species of the genus Rhodovulum

Symbols: + , substrate utilized or present; $(+)$, some strains utilizing the substrate and some not; -, substrate not utilized or absent; NT, not tested. References: a, Kompantseva (1985), Imhoff \& Trüper (1992); b, Hiraishi \& Ueda, (1995); c, Straub et al. (1999); d, Hansen \& Veldkamp, (1973), Imhoff \& Trüper (1992), Heising et al. (1996); e, Neutzling et al. (1984).

\begin{tabular}{|c|c|c|c|c|c|c|c|}
\hline Characteristics & $\mathrm{JA}_{128^{\mathrm{T}}{ }}$ & $\begin{array}{l}\text { Rhodovulum } \\
\text { euryhalinum }^{\mathrm{a}}\end{array}$ & $\begin{array}{l}\text { Rhodovulum } \\
\text { strictum }^{\mathrm{b}}\end{array}$ & $\begin{array}{l}\text { Rhodovulum } \\
\text { iodosum }^{c}\end{array}$ & $\begin{array}{l}\text { Rhodovulum } \\
\text { robiginosum }^{\mathrm{c}}\end{array}$ & $\begin{array}{l}\text { Rhodovulum } \\
\text { sulfidophilum }^{\mathrm{d}}\end{array}$ & $\begin{array}{l}\text { Rhodovulum } \\
\text { adriaticum }^{\mathrm{e}}\end{array}$ \\
\hline Cell diameter $(\mu \mathrm{m})$ & $0 \cdot 6-0 \cdot 8$ & $0 \cdot 7-1 \cdot 0$ & $0 \cdot 6-1 \cdot 0$ & $0 \cdot 5-0 \cdot 8$ & $0 \cdot 5-0 \cdot 8$ & $0 \cdot 6-1 \cdot 0$ & $0 \cdot 5-0 \cdot 8$ \\
\hline Motility & Non-motile & $\begin{array}{l}\text { Motile, polar } \\
\text { flagella }\end{array}$ & $\begin{array}{l}\text { Motile, polar } \\
\text { flagella }\end{array}$ & Non-motile & Non-motile & $\begin{array}{l}\text { Motile, polar } \\
\text { flagella }\end{array}$ & Non-motile \\
\hline $\mathrm{pH}$ range & $5 \cdot 5-7 \cdot 5$ & $6 \cdot 0-8 \cdot 5$ & $7 \cdot 5-9 \cdot 0$ & & & $5 \cdot 0-9 \cdot 0$ & $6 \cdot 0-8 \cdot 5$ \\
\hline Optima & $6 \cdot 0-6 \cdot 8$ & & & $6 \cdot 5$ & $6 \cdot 5$ & & \\
\hline Chemo-organotrophy & + & - & + & + & + & + & - \\
\hline $\begin{array}{l}\text { Temperature range } \\
\text { (optimum) }\left({ }^{\circ} \mathrm{C}\right)\end{array}$ & $25-35(30)$ & - & $30-35$ & $20-25$ & $25-28$ & $(25)$ & $25-30$ \\
\hline \multicolumn{8}{|l|}{ Inorganic } \\
\hline Hydrogen & - & NT & NT & + & + & + & - \\
\hline Sulfide & - & + & + & + & + & + & + \\
\hline Thiosulfate & - & + & + & + & + & + & + \\
\hline Sulfur & - & NT & NT & + & + & + & NT \\
\hline Ferrous iron & - & - & NT & + & + & + & - \\
\hline \multicolumn{8}{|l|}{ Organic } \\
\hline Formate & - & + & + & - & - & + & + \\
\hline Acetate & + & + & + & + & + & + & + \\
\hline Propionate & - & + & + & + & + & + & + \\
\hline Butyrate & - & + & + & + & - & + & - \\
\hline Fumarate & + & + & + & + & - & + & + \\
\hline Malate & - & + & + & + & + & + & + \\
\hline Citrate & - & - & $(+)$ & - & - & - & - \\
\hline Benzoate & - & - & - & - & - & - & - \\
\hline Aspartate & - & + & - & - & - & - & NT \\
\hline Cysteine & - & NT & NT & + & - & NT & NT \\
\hline Glutamate & - & + & - & + & + & + & NT \\
\hline Glucose & + & + & + & - & - & + & + \\
\hline Fructose & + & + & + & - & - & - & - \\
\hline Glycerol & + & + & - & - & + & + & + \\
\hline Mannitol & + & + & - & + & + & - & - \\
\hline
\end{tabular}

${ }^{\star}$ Organic substrate utilization was tested during photoheterotrophic growth.

$\dagger \mathrm{b}$, Biotin; $\mathrm{n}$, niacin; paba, $p$-aminobenzoate; $\mathrm{t}$, thiamine. 
Genomic DNA was extracted and purified according to the method of Marmur (1961) and the G+C content of the DNA was determined by thermal denaturation (Marmur \& Doty, 1962). Cell material for $16 \mathrm{~S}$ rRNA gene sequencing was taken from 1-2 $\mathrm{ml}$ of well grown liquid cultures. DNA was extracted and purified by using the Qiagen genomic DNA buffer set. PCR amplification and 16S rRNA gene sequencing was done as described previously (Imhoff et al., 1998a; Imhoff \& Pfennig, 2001). Sequences were aligned using the CLUSTAL W program (Thompson et al., 1994) and the alignment was corrected manually. The distance matrix was calculated on the basis of the algorithm according to Jukes \& Cantor (1969) with the DNADIST program within the PHYLIP package (Felsenstein, 1989). The FITCH program in the PHYLIP package was used to fit a tree to the evolutionary distances.

Samples were collected during March 2004 from Ramakrishna beach, Visakhapatnam, Bay of Bengal, on the east coast of India $\left(17 \cdot 7^{\circ}\right.$ longitude, $83 \cdot 32^{\circ}$ latitude). The sample yielding strain JA128 ${ }^{\mathrm{T}}$ had a $\mathrm{pH}$ of $6 \cdot 8$ and a salinity of $2-3 \% \mathrm{NaCl}$, and the temperature was $30^{\circ} \mathrm{C}$. The sample was inoculated into sterile screw cap tubes filled with medium for photoheterotrophic growth and incubated in the light for 1 week with intermittent shaking. Yellowishbrown enrichments were obtained and subcultured into the same medium. This culture was used for subsequent agar shake dilution series for purification. After 4 days incubation, small, convex, yellowish-brown colonies were observed. The colony and cell morphology were the same in all dilution series. The culture was maintained by repeated subculturing in the same medium and also in stabs. The stabs were preserved in a refrigerator at $4{ }^{\circ} \mathrm{C}$. Individual cells of strain JA $128^{\mathrm{T}}$ were oval to rod-shaped (Fig. $1 \mathrm{a}$ ), $0 \cdot 6-0 \cdot 8 \mu \mathrm{m}$ wide and 1-2 $\mu \mathrm{m}$ long. The cells were non-motile and multiplied by binary fission (Fig. 1b). Electron microphotographs of ultrathin sections of the cells revealed vesicular internal membranes (Fig. 1c).

Strain $\mathrm{JA} 128^{\mathrm{T}}$ can grow photo-organoheterotrophically (optimum light intensity is 2000-4000 lux) and chemoorganoheterotrophically (aerobically in the dark). It tolerates the atmospheric level of oxygen. Photolithoautotrophic growth [anaerobic, light (2400 lux), $\mathrm{H}_{2}(20 \%$, v/v)/ $\mathrm{Na}_{2} \mathrm{~S}, \mathrm{Na}_{2} \mathrm{~S}_{2} \mathrm{O}_{3}(0.5 \mathrm{mM}), \mathrm{NaHCO}_{3}(0 \cdot 1 \%$, w/v)], chemolithoautotrophic growth [aerobic, dark, thiosulfate $(0.5 \mathrm{mM})$, $\left.\mathrm{NaHCO}_{3}(0 \cdot 1 \%, \mathrm{w} / \mathrm{v})\right]$ and fermentative growth (anaerobic, dark with glucose/fructose $(0 \cdot 3 \%, \mathrm{w} / \mathrm{v})]$ could not be demonstrated. The substrates which were utilized (Table 1) as carbon/electron donor under photo-organoheterotrophic conditions include acetate, pyruvate, lactate, succinate, fumarate, oxaloacetate, tartrate, glucose, fructose, mannitol, sorbitol, glycerol, ethanol, yeast extract and Casamino acids. Those which could not be utilized include formate, propionate, butyrate, valerate, caproate, oleic acid, citrate, $\alpha$-ketoglutarate, malate, sucrose, lactose, maltose, methanol, glutamate and benzoate. Thiosulfate, sodium sulfide and $\mathrm{H}_{2}$ (with $0 \cdot 1 \% \mathrm{NaHCO}_{3}$ ) were not utilized as electron donors under photolithoautotrophic conditions. Ammonium chloride, molecular nitrogen, nitrate, glutamate and glutamine were utilized as nitrogen sources, while urea and nitrite did not support growth. Salt $(\mathrm{NaCl})$ was obligatory for growth, and growth occurred from 0.05 to $8 \%(\mathrm{w} / \mathrm{v})$, the optimum $\mathrm{NaCl}$ concentration being $1-3 \%(\mathrm{w} / \mathrm{v})$. This is similar to the observed growth of another marine isolate from India, Marichromatium indicum $\mathrm{JA}_{100}{ }^{\mathrm{T}}$ (Arunasri et al., 2005), which also grows in a range of $0 \cdot 05-8 \% \mathrm{NaCl}$, reflecting adaptation to a natural habitat in which large variations in the salt concentration during various seasons occurs. The $\mathrm{pH}$ range for growth of strain $\mathrm{JA} 128^{\mathrm{T}}$ was $5 \cdot 5-7 \cdot 5$ with the optimum at $6 \cdot 0-6 \cdot 8$. The temperature range was from 25 to $35^{\circ} \mathrm{C}$ and the optimum was at $30^{\circ} \mathrm{C}$. Thiamine was required as growth factor. The colour of photosynthetically grown cell suspensions was yellowish-brown to beige. The cell absorption spectrum (Fig. 2a) of strain JA12 $28^{\mathrm{T}}$ gave maxima at $378,402,488,520,590,802,884 \mathrm{~nm}$, confirming the presence of bacteriochlorophyll $a$ and most probably the carotenoids spheroidene and spheroidenone (Fig. 2b).

The DNA base composition of strain JA128 ${ }^{\mathrm{T}}$ was $62 \mathrm{~mol} \%$ $\mathrm{G}+\mathrm{C}\left(T_{\mathrm{m}}\right)$. The phylogenetic relationship of strain JA128 ${ }^{\mathrm{T}}$ to other purple non-sulfur bacteria was examined by $16 \mathrm{~S}$ rRNA gene sequencing. The data obtained revealed that the sequence of the new isolate formed a separate branch in the cluster of the genus Rhodovulum (Fig. 3), but was distinct from other genera of purple non-sulfur bacteria. The highest sequence similarities to strain $\mathrm{JA} 128^{\mathrm{T}}$ were
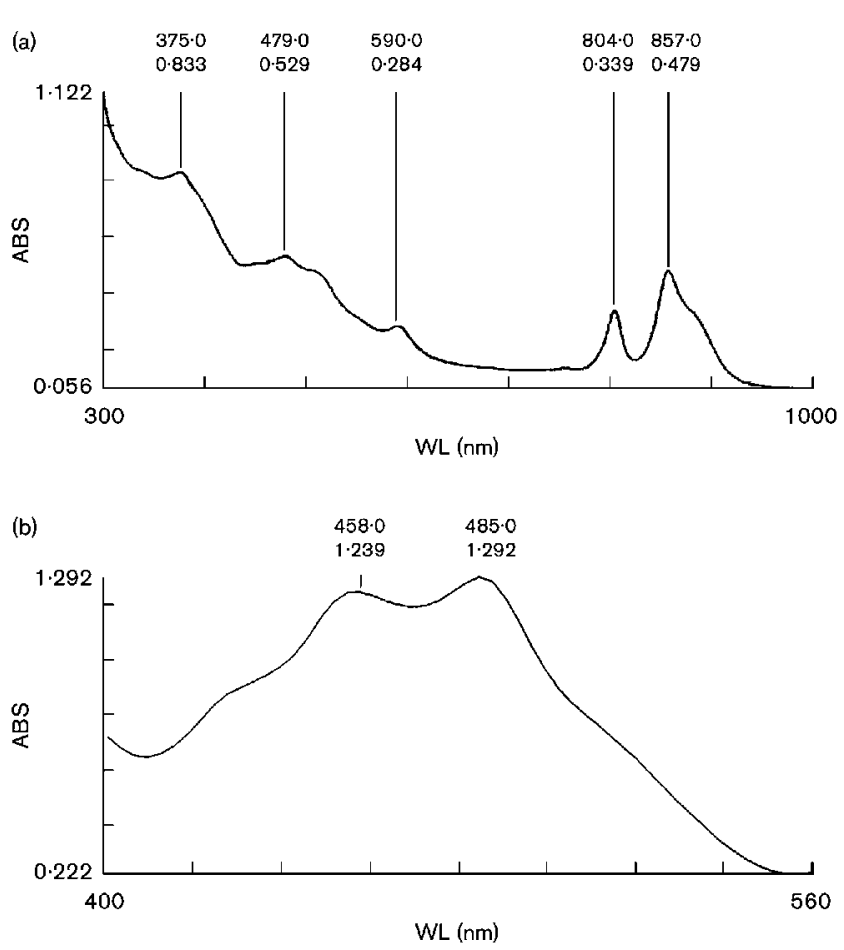

Fig. 2. Whole-cell absorption spectrum (a) of strain $J A 128^{\top}$ and acetone spectrum (b) of extracted pigments. 


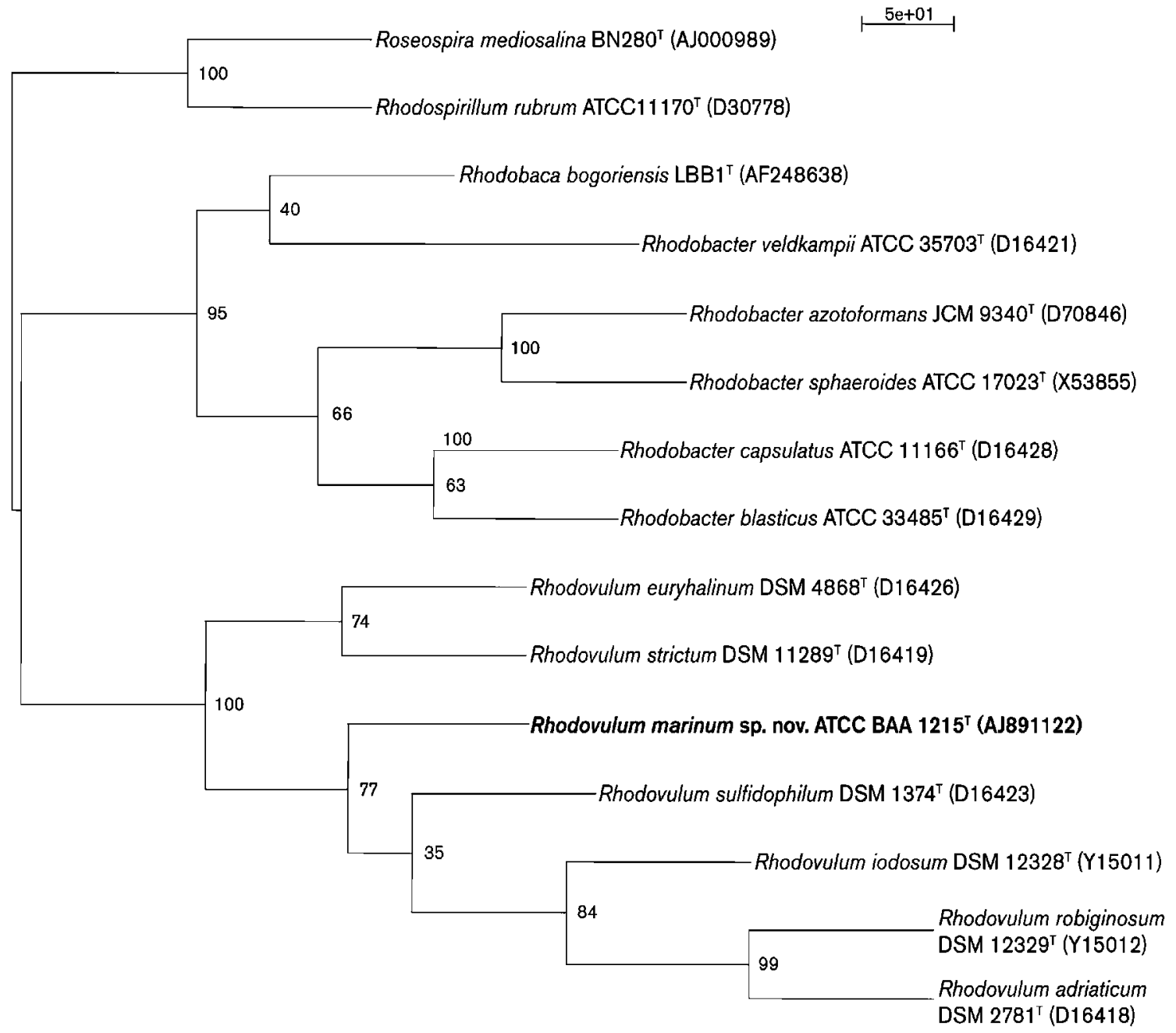

Fig. 3. Dendrogram depicting the phylogenetic relationships of strain JA128 within the family Rhodobacteriaceae determined using $16 \mathrm{~S}$ rRNA gene sequence analysis. Bar, $1 \mathrm{nt}$ substitution per $100 \mathrm{nt}$.

found with the type strains of Rhodovulum iodosum, Rhodovulum sulfidophilum (95\%) and Rhodovulum robiginosum (93\%). Apart from 16S rRNA gene sequence dissimilarity, strain $\mathrm{JA} 128^{\mathrm{T}}$ showed phenotypic differences to other Rhodovulum species (Table 1) that justify the description of this strain as a novel species.

\section{Description of Rhodovulum marinum sp. nov.}

Rhodovulum marinum (ma.ri' num. L. neut. adj. marinum of the sea, marine).

Cells are ovoid to rod-shaped, $0 \cdot 6-0 \cdot 8 \mu \mathrm{m}$ wide, $1 \cdot 0$ $2 \cdot 0 \mu \mathrm{m}$ long and form chains. Non-motile and division by binary fission. Gram-negative. Growth occurs under anaerobic conditions in the light (photo-organoheterotrophy) or under aerobic conditions in the dark (chemo-organoheterotrophy). Internal photosynthetic membranes are vesicular. The colour of phototrophic cultures is yellow-green to brown, while aerobic cultures are pink. The in vivo absorption spectrum of intact cells in sucrose exhibits maxima at 375, 479, 590, 804 and $857 \mathrm{~nm}$. Photosynthetic pigments are bacteriochlorophyll $a$ and most probably carotenoids of the spheroidene series. The type strain is mesophilic (range $25-35^{\circ} \mathrm{C}$, optimum $30^{\circ} \mathrm{C}$ ), slightly acidophilic (pH range $5 \cdot 5-7 \cdot 5$, optimum $6 \cdot 0-6 \cdot 8$ ) and slightly halophilic with $\mathrm{NaCl}$ concentrations of 0.5 to $3.0 \%$ required for optimal growth. Photo-organotrophy with various organic compounds is the preferred mode of growth. Good carbon sources are sorbitol, mannitol, pyruvate, lactate, intermediates of the citric acid cycle and some sugars. Growth on acetate, glycerol and ethanol also occurs. Photoautotrophic and chemoautotrophic growth is not possible in the presence of sulfide, thiosulfate or hydrogen as electron donor and $\mathrm{NaHCO}_{3}$ as carbon source. Thiamine is required as growth factor. DNA G $+\mathrm{C}$ base composition: $62 \mathrm{~mol} \%\left(T_{\mathrm{m}}\right)$. Natural habitats are marine surface and tidal waters exposed to light. The EMBL accession number for the $16 \mathrm{~S}$ rRNA gene sequence of strain $\mathrm{JA} 128^{\mathrm{T}}$ is 
AJ891122. The type strain, JA128 ${ }^{\mathrm{T}}$, has been deposited as ATCC BAA $1215^{\mathrm{T}}=\mathrm{JCM} 13300^{\mathrm{T}}=$ CCUG $52183^{\mathrm{T}}$.

\section{Acknowledgements}

Financial assistance received from the Department of Ocean Development, the Department of Biotechnology, the Government of India and the DST-DAAD exchange program (grant 422-PPP-34105) is acknowledged. A.P. and T. N. R.S. acknowledge the CSIR, Government of India, for the award of research fellowships. The skilful assistance of F. Lappe (IFM-GEOMAR, Kiel, Germany) in molecular analysis is kindly acknowledged.

\section{References}

Arunasri, K., Sasikala, C., Ramana, C. V., Süling, J. \& Imhoff, J. F. (2005). Marichromatium indicum sp. nov., a novel purple sulfur gammaproteobacterium from mangrove soil of Goa, India. Int J Syst Evol Microbiol 55, 673-679.

Felsenstein, J. (1989). PHYLIP - Phylogenetic Inference Package, version 3.5.1. Distributed by the author. University of Washington, Seattle, USA.

Hansen, T. A. \& Veldkamp, H. (1973). Rhodopseudomonas sulfidophila, nov. spec., a new species of the purple nonsulfur bacteria. Arch Microbiol 92, 45-58.

Heising, S., Dilling, W., Schnell, S. \& Schink, B. (1996). Complete assimilation of cysteine by a newly isolated non-sulfur purple bacterium resembling Rhodovulum sulfidophilum (Rhodobacter sulfidophilus). Arch Microbiol 165, 397-401.

Hiraishi, A. \& Ueda, Y. (1994). Intrageneric structure of the genus Rhodobacter: transfer of Rhodobacter sulfidophilus and related marine species to the genus Rhodovulum gen. nov. Int J Syst Bacteriol 44, $15-23$.

Hiraishi, A. \& Ueda, Y. (1995). Isolation and characterization of Rhodovulum strictum sp. nov. and some other purple nonsulfur bacteria from colored blooms in tidal and seawater pools. Int J Syst Bacteriol 45, 319-326.

Imhoff, J. F. (1983). Rhodopseudomonas marina sp. nov., a new marine phototrophic purple bacterium. Syst Appl Microbiol 4, 512-521.

Imhoff, J. F. (1988). Anoxygenic phototrophic bacteria. In Methods in Aquatic Bacteriology, pp. 207-240. Edited by B. Austin. Chichester, New York: Wiley.

Imhoff, J. F. (2001). Transfer of Rhodopseudomonas acidophila to the new genus Rhodoblastus as Rhodoblastus acidophilus gen. nov., comb. nov. Int J Syst Bacteriol Microbiol 51, 1863-1866.

Imhoff, J. F. \& Pfennig, N. (2001). Thioflavicoccus mobilis gen. nov., sp. nov., a novel purple sulfur bacterium with bacteriochlorophyll $b$. Int J Syst Bacteriol Microbiol 51, 105-110.

Imhoff, J. F. \& Trüper, H. G. (1992). The genus Rhodospirillum and related genera. In the Prokaryotes, 2nd edn, pp. 2141-2155. Edited by A. Balows, H. G. Trüper, M. Dworkin, W. Harder \& K.-H. Schleifer. Berlin, Heidelberg, New York: Springer.

Imhoff, J. F., Süling, J. \& Petri, R. (1998a). Phylogenetic relationships among the Chromatiaceae, their taxonomic reclassification and description of the new genera Allochromatium, Halochromatium, Isochromatium, Marichromatium, Thiococcus, Thiohalocapsa and Thermochromatium. Int J Syst Bacteriol 48, 1129-1143.
Imhoff, J. F., Süling, J. \& Petri, R. (1998b). Reclassification of species of the spiral-shaped phototrophic purple non-sulfur bacteria of the $\alpha$-Proteobacteria : description of the new genera Phaeospirillum gen. nov., Rhodovibrio gen. nov., Rhodothalassium gen. nov. and Roseospira gen. nov. as well as transfer of Rhodospirillum fulvum to Phaeospirillum fulvum comb. nov., of Rhodospirillum molischianum to Phaeospirillum molischianum comb. nov., of Rhodospirillum salinarum to Rhodovibrio salinarum comb. nov., of Rhodospirillum sodomense to Rhodovibrio sodomensis comb. nov., of Rhodospirillum salexigens to Rhodothalassium salexigens comb. nov. and of Rhodospirillum mediosalinum to Roseospira mediosalina comb. nov. Int J Syst Bacteriol 48, 793-798.

Jukes, T. H. \& Cantor, C. R. (1969). Evolution of protein molecules. In Mammalian Protein Metabolism, pp. 21-132. Edited by H. N. Munro. New York: Academic Press.

Karr, E. A., Sattley, W. M., Jung, D. O., Madigan, M. T. \& Achenbach, L. A. (2003). Remarkable diversity of phototrophic purple bacteria in a permanently frozen Antarctic lake. Appl Environ Microbiol 69, 4910-4914.

Kompantseva, E. I. (1985). New halophilic purple bacteria Rhodobacter euryhalinus sp. nov. Mikrobiologiia 54, 974-982.

Madigan, M. T., Jung, D. O., Woese, C. R. \& Achenbach, L. A. (2000). Rhodoferax antarcticus sp. nov., a moderately psychrophilic purple non-sulfur bacterium isolated from an Antarctic microbial mat. Arch Microbiol 173, 269-277.

Marmur, J. (1961). A procedure for the isolation of deoxyribonucleic acid from microorganisms. J Mol Biol 3, 208-218.

Marmur, J. \& Doty, P. (1962). Determination of the base composition of deoxyribonucleic acid from its thermal denaturation temperature. J Mol Biol 5, 109-118.

Neutzling, O., Imhoff, J. F. \& Trüper, H. G. (1984). Rhodopseudomonas adriatica sp. nov., a new species of the Rhodospirillaceae, dependent on reduced sulfur compounds. Arch Microbiol 137, 256-261.

Pfennig, N. \& Trüper, H. G. (1974). The phototrophic bacteria. In Bergey's Manual of Systematic Bacteriology, 8th edn, pp. 24-75. Edited by R. E. Buchanan \& N. E. Gibbons. Baltimore: Williams \& Wilkins.

Pfennig, N. \& Trüper, H. G. (1989). Family Chromatiaceae. In Bergey's Manual of Systematic Bacteriology, vol. 3, pp. 1637-1653. Edited by J. T. Staley, M. P. Bryant. N. Pfennig \& J. G. Holt. Baltimore: Williams \& Wilkins.

Pfennig, N. \& Trüper, H. G. (1992). The family Chromatiaceae. In the Prokaryotes. A Handbook on the Biology of Bacteria. Ecophysiology, Isolation, Identification, Applications, 2nd edn, pp. 3200-3221. Edited by A. Balows, H. G. Trüper, M. Dworkin, W. Harder \& K.-H. Schleifer. Berlin, Heidelberg \& New York: Springer.

Straub, K. L., Rainey, F. A. \& Widdel, F. (1999). Rhodovulum iodosum sp. nov. and Rhodovulum robiginosum sp. nov., two new marine phototrophic ferrous-iron-oxidizing purple bacteria. Int $J$ Syst Bacteriol 49, 729-735.

Thompson, J. D., Higgins, D. G. \& Gibson, T. J. (1994). CLUSTAL W: improving the sensitivity of progressive multiple sequence alignment through sequence weighting, position-specific gap penalties and weight matrix choice. Nucleic Acids Res 22, 4673-4680.

Trüper, H. G. \& Pfennig, N. (1981). Isolation of members of the families Chromatiaceae and Chlorobiaceae. In the Prokaryotes: a Handbook on Habitats, Isolation, and Identification of Bacteria, pp. 279-289. Edited by M. P. Starr, H. Stolp, H. G. Trüper, A. Balows \& H. G. Schlegel. Berlin: Springer. 